\title{
Transformation of beech forest litter as a factor that triggers arsenic solubility in soils developed on historical mine dumps
}

\author{
Anna Karczewska ${ }^{1}$ D $\cdot$ Karolina Lewińska $^{2} \cdot$ Marcin Siepak $^{3} \cdot$ Bernard Gałka $^{1} \cdot$ Agnieszka Dradrach $^{4} \cdot$ Katarzyna Szopka $^{1}$
}

Received: 2 October 2017 / Accepted: 15 May 2018 / Published online: 30 May 2018

(C) The Author(s) 2018

\begin{abstract}
Purpose Soils that develop on the dumps in historical arsenic mining sites contain high concentrations of As thus constituting a serious environmental risk. This study was aimed to examine the changes in arsenic solubility in mine soils as induced by organic matter introduced with forest litter.

Materials and methods Four large samples of initially developed soils were collected from the dumps remaining in former mining sites and were incubated for 90 days at various moistures: $80 \%$ of maximum water holding capacity and $100 \%$ (flooded conditions), with and without addition of beech forest litter (BL), $50 \mathrm{~g} / \mathrm{kg}$. Soils contained up to $5.0 \%$ As. Soil pore water was collected periodically with MacroRhizon suction samplers and examined on As, Mn, and $\mathrm{Fe}$ concentrations, $\mathrm{pH}$, Eh, and dissolved organic carbon (DOC). The properties of dissolved organic matter were characterized by UV-VIS spectroscopic parameters A4/A6 and $\mathrm{SUVA}_{254}$.

Results and discussion Application of BL resulted in an intensive release of As from soils, particularly at 100\% moisture. As concentrations in soil pore water increased strongly during the first 2 or 4 weeks of incubation and then started to decrease in all cases, except for one flooded soil. As was released particularly intensively from carbonate-containing soils. The mechanisms of As mobilization, including reductive dissolution of $\mathrm{Mn}$ and Fe oxides and the competition with DOC for sorption sites on the oxides, were discussed as related to soil properties. Pore water concentrations of DOC were increasing at the beginning of incubation and started to decrease after two or four weeks. Spectroscopic parameters of dissolved organic matter in ZS soils indicated increasing aromaticity and progress of humification.

Conclusions Forest litter introduced to mine dump soils causes a mobilization of As into soil pore water. This effect, particularly strong in carbonate-rich soils, is apparently related to high concentrations of DOC and usually declines with time, which may be explained by the progress in humification. The relationships between DOC properties and As speciation in soil pore water should be dissected for better interpretation of experimental results.
\end{abstract}

Keywords Arsenic · Dump · Dissolved organic carbon · Incubation · MacroRhizon · Organic matter · Pore water

Responsible editor: Anja Miltner

Electronic supplementary material The online version of this article (https://doi.org/10.1007/s11368-018-2031-2) contains supplementary material, which is available to authorized users.

Anna Karczewska

anna.karczewska@upwr.edu.pl

1 Institute of Soil Science and Environmental Protection, Wroclaw University of Environmental and Life Sciences, ul. Grunwaldzka 53, 50-357 Wrocław, Poland
2 Department of Soil Science and Remote Sensing of Soils, Adam Mickiewicz University in Poznań, ul. Krygowskiego 10, 61-680 Poznań, Poland

3 Institute of Geology, Adam Mickiewicz University in Poznań, ul. Krygowskiego 12, 61-680 Poznań, Poland

4 Department of Agroecosystems and Green Areas Management, Wroclaw University of Environmental and Life Sciences, pl. Grunwaldzki 24a, 50-350 Wrocław, Poland 


\section{Introduction}

Arsenic is a toxic element; therefore, its mobility in the environment and lability in soil are a matter of concern (Wenzel 2013). Arsenic concentrations in Polish soils are basically very low, but there are sites associated with historical ore mining, where arsenic occurs in very high concentrations (Karczewska et al. 2007, 2013b; Krysiak and Karczewska 2007). Particularly, high amounts of As were recorded in mine dumps. The release of As from dump material may likely be caused by weathering, leaching, and other processes. Arsenic species strongly bound to iron, aluminum, and manganese oxides form usually the main pool of As in soils (Bauer and Blodau 2006; Wenzel 2013). However, especially in soils where total As concentration is high, a substantial amount of As may remain as potentially soluble or exchangeable. Under certain conditions, however, arsenic distribution in soil can be modified causing the release of its considerable amounts from soil solid phase into soil solution. Such an effect may be caused by the presence of anions, such as phosphates, that compete with arsenates for oxide sorption sites and also by the changes in soil $\mathrm{pH}$ or redox potential (Bolan et al. 2013; Lewińska and Karczewska 2013; Wenzel 2013; Arco-Lázaro et al. 2016). Important parameters that affect the processes of As sorption and desorption are soil $\mathrm{pH}$ (Carbonell-Barrachina et al. 1999; Wenzel 2013; Komárek et al. 2013), as well as the presence or absence of carbonates. Fakhreddine et al. (2015) stressed that $\mathrm{Ca}^{2+}$ and $\mathrm{Mg}^{2+}$ cations present in water at high concentrations foster arsenate adsorption to the phyllosilicate clay minerals, while at the absence of those cations in water As gets easily released from the sediments into solution. However, Kim et al. (2000) and Han et al. (2007) proved that the presence of carbonates in soil may cause enhanced release of arsenic (As III) under anoxic conditions due to formation of stable arseno-carbonate complexes, believed to be $\mathrm{As}\left(\mathrm{CO}_{3}\right)_{2}{ }^{-}$, $\mathrm{As}\left(\mathrm{CO}_{3}\right)(\mathrm{OH})_{2}{ }^{-}$, and $\mathrm{AsCO}_{3}{ }^{+}$.

Application of organic matter is another factor that may affect the distribution of As in soils, thus changing its potential solubility. Various authors reported increased solubility of heavy metals and arsenic in soils caused by the presence of plant cover or induced by the products that are formed in soils from decomposing plant residues. In particular, the processes of forest litter transformation may lead to increased solubility of various elements, as they deliver organic and inorganic compounds into draining water, stimulate biological activity, and additionally may affect redox conditions (Kalbitz and Wennrich 1998; Karczewska et al. 2013a, 2017; Kabała et al. 2014; Berg 2017; Cuske et al. 2017).

The effects of organic matter on the solubility of As in soils depend obviously on its properties, but almost all the recent studies proved that both dissolved and particulate or solid organic matter may cause an increased solubility of As, contrary to the effects that high molecular weight organic matter poses on typical heavy metals. The main mechanisms involved in As release from soil in the presence of organic matter include competition for available adsorption sites, formation of aqueous complexes, and changes in the redox potential (Wang and Mulligan 2006). Not many papers were published that reported As bonding to solid or aqueous humic substances (Thanabalasingam and Pickering 1986; Silvetti et al. 2017; Saada et al. 2003).

Several studies carried out with forest soils concluded that As did not accumulate in forest litter and that the concentrations of As in a humus layer are usually much lower than those in underlying mineral horizons of As-enriched soils (Blaser et al. 2000; Karczewska et al. 2013b). Some authors reported, however, accumulation of As in peat and in organic soils, as well as in the forest humus (González et al. 2006; Brun et al. 2008; Langner et al. 2012), but a thorough insight in the balance of As in forest humus provides a divergent picture, related strongly to climatic conditions. Generally, in the conditions of high humidity, As indicated the tendency to being leached from forest litter (Brun et al. 2008).

Various factors and mechanisms are involved in the processes of As mobilization from soils by organic matter, in particular by dissolved organic matter (DOM), including sorption/desorption, sorption competition, redox reactions, complexation, and colloid formation (Bauer and Blodau 2006; Wang and Mulligan 2006; Moreno-Jiménez et al. 2013; Xie et al. 2015). Various soil moisture conditions, with special case of waterlogging, are of crucial importance in terms of As solubility, as they determine soil redox potential and govern the processes of organic matter transformation. The products derived from plant residues decomposing under oxidized and anoxic conditions differ considerably if considering their properties, including molecular size, aromaticity, and the kinds of functional groups ( $\mathrm{Labaz}$ et al. 2016; Berg 2017; Kawałko et al. 2017). These factors are important for the run of sorption/desorption processes or organic matter complexing properties. Humic substances together with nonspecific organic compounds make a complex mixture of products that cannot be described by simple chemical formulas (Chen et al. 1977; Swift 1996). Therefore, various indices are used to depict the concentrations and features of soil organic matter. The indices most commonly used to characterize organic compounds dissolved in water are DOC concentrations and optical properties based on spectral characteristics of light absorption in the ranges of UV, VIS, and IR. Specific UV absorbance $\mathrm{SUVA}_{254}$ is defined as the UV absorbance of water sample at $254 \mathrm{~nm}$, measured in inverse meters $(1 / \mathrm{m})$, related to the concentration of DOC (in $\mathrm{mg} / \mathrm{L}$ ). $\mathrm{SUVA}_{254}$ is an average absorptivity of all the organic molecules comprised within the DOC in a water or soil solution sample. It may be used as a surrogate index of DOC aromaticity (Weishaar et al. 2003). The A4:A6 parameter (often denoted as E4:E6) provides a simplified information on the humification degree of 
organic matter (Chen et al. 1977; Strobel et al. 2001; Łabaz and Gałka 2012; Łabaz et al. 2016).

Under anoxic conditions, the concentrations of DOC in the soil solution underneath the forest floor are commonly elevated, due to the absence of oxide sorption sites (caused by podzolization processes) and greatly reduced microbial activity. In such conditions, easily degradable organic compounds tend to concentrate in soil pore water (Marschner and Kalbitz 2003) and compete with inorganic ions for soil sorption sites. Anoxic conditions are of particular importance for the release of As from soil solid phase due to reductive dissolution of FeOx (Komárek et al. 2013; Wenzel 2013) driven by the drop in redox potential (Eh). Several studies have shown, however, that the As release from enriched soils depends on its speciation and stability of As-sorbing oxides, which means that the most tightly bound As forms remain permanent and will not be released even in waterlogging conditions (Weber et al. 2009; Krysiak and Karczewska 2011; Komárek et al. 2013; Martin et al. 2014). Additionally, the dynamics of watersoluble As in soils is controlled by the period of flooding (Shaheen et al. 2014).

This study was aimed to examine the release of As into soil solution from mine dump soils differing in properties, as affected by introduction of organic matter in a form of forest beech litter, and incubated in various moisture conditions, including waterlogging. Similar studies on mine soils were only occasionally performed (Kalbitz and Wennrich 1998; Karczewska et al. 2013a; Van Nevel et al. 2013, 2014; Cuske et al. 2017) and their results indicated the risk of forest litterinduced release of metals and metalloids from polluted soils.

\section{Materials and methods}

\subsection{Site description}

Soils at initial stage of pedogenesis, developing from weathered waste rock material of mine dumps, were collected in a historical site of former Au and As mining in Złoty Stok (ZS1, ZS2) and in the sites of polymetallic ore mining in the villages of Radzimowice (R) and Dziećmorowice (DM) (Fig. 1). Those sites have different geological settings and ore mineralogy and consequently differ in the properties of waste rocks. Złoty Stok, formerly German Reichenstein, was known from environmental arsenicalism, i.e., the cases of arsenic caused diseases (Kathe 1937; Hindmarsh et al. 1977). Ore mineralization in Złoty Stok is related to metamorphogenic, hydrothermal As-Au deposits that formed in a dislocation zone. Development of arsenic ores was associated there with serpentinization of dolomitic marbles and formation of
Fig. 1 Location of historical mines (and sampling sites): Złoty Stok (ZS1, ZS2), Radzimowice (R) and Dziećmorowice (DM) in the Sudety Mts., SW Poland

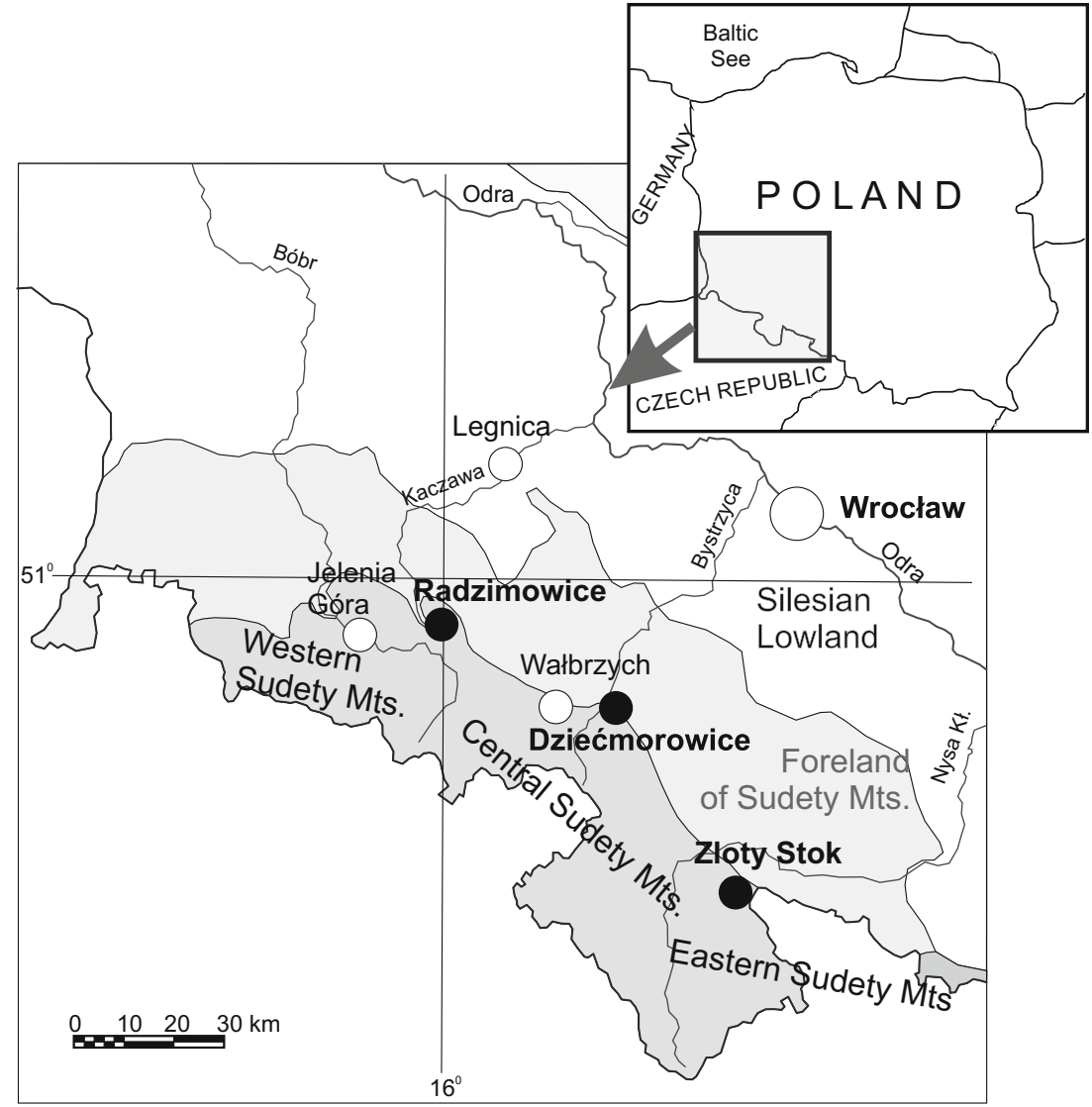


various calc-silicate skarn-type rocks (Wierchowiec and Wojciechowski 2010). The ores in Radzimowice represent moderate and low temperature mineral associations that developed in postmagmatic hydrothermal processes around a rhyolite subvolcanic intrusion of the hill Żeleźniak (Mikulski 1999). Ore mineralization in DM is associated with quartzbarite and barite-calcite veins that represent low temperature crystallization, related to Early Permian porphyries that fill dislocations in the gneisses and migmatites of the Sowie Mts block (Muszer et al. 2006).

\subsection{Soils}

Four large soil samples were collected from the dumps, crushed, and sieved on site to determine the percentage of skeleton and earthy soil $(<2 \mathrm{~mm})$ and then brought to laboratory, air-dried, and homogenized prior to the experiment. Aliquots of the fine earth fraction were analyzed for basic soil properties (Table 1) by standard methods (Tan 2005). Soil texture was determined by a hydrometer method. Organic carbon and carbonate content was determined by an analyzer CS-MAT 5500, Strohlein, total $\mathrm{N}$ by Kjeldahl method, $\mathrm{pH}\left(\mathrm{H}_{2} \mathrm{O}\right)$ by potentiometry, and amorphous forms of Fe oxides (Feox) in oxalate extraction. Total As was determined by ICP-AES (Thermo Scientific, iCAP 7400), after microwave-assisted digestion with aqua regia (USEPA 3051a). The accuracy of analytical method was checked by using two certified reference materials, CNS392 and CRM044, supplied by SigmaAldrich. Recovery of As was in the range $92-106 \%$ in case of CNS 392 (with reference value of $6.49 \mathrm{mg} / \mathrm{kg}$ ) and 95 $104 \%$ in case of CRM044 (with reference at $57.4 \mathrm{mg} / \mathrm{kg}$ ). To assess the amounts of As easily soluble in soils, commonly accepted extractions with $0.01 \mathrm{M} \mathrm{CaCl}_{2}$ and $1 \mathrm{M}$ $\mathrm{NH}_{4} \mathrm{NO}_{3}$ were performed, according to the procedure by Houba et al. (2000) and ISO 19730 ( 2008), respectively.

\subsection{Forest litter}

Beech forest litter (BL) used in the experiment was collected in an early spring (end of March 2016) from a 60-year-old beech woodland. It represented a typical mull with a 15-25cm-thick layer of partly decomposed and transformed beech foliage. The thickness of this layer tended to decline strongly during the year, and there was no a humification layer. The beech litter was air-dried, crumbled, and sieved to $1 \mathrm{~cm}$. Its analysis involved determination of moisture, organic carbon content (determined by a carbon analyzer CS-MAT 5500, Strohlein), $\mathrm{pH}$ in water suspension, and dissolved organic carbon (DOC) extracted in cold water, according to the method by Gregorich et al. (2003) and determined by a TOC 5000 Shimadzu analyzer.

Table 1 Soil origin and basic soil properties

\begin{tabular}{|c|c|c|c|c|c|c|}
\hline \multirow{2}{*}{$\begin{array}{l}\text { Parameter } \\
\text { Symbol }\end{array}$} & & \multirow[t]{2}{*}{ Unit } & \multicolumn{4}{|l|}{ Soil } \\
\hline & & & ZS 1 & ZS 2 & $\mathrm{R}$ & $\mathrm{DM}$ \\
\hline \multirow[t]{3}{*}{ Origin } & Object & - & Mine dump & Mine dump & Mine dump & Mine dump \\
\hline & Locality & - & Złoty Stok & Złoty Stok & Radzimowice & Dziećmorowice \\
\hline & Mined ores & - & $\mathrm{Au}$ and $\mathrm{As}$ & $\mathrm{Au}$ and $\mathrm{As}$ & polymetallic & polymetallic \\
\hline \multicolumn{2}{|l|}{ Skeleton (> $2 \mathrm{~mm}$ ) } & $\%$ & 80 & 50 & 60 & 60 \\
\hline \multirow[t]{3}{*}{ Share in fine soil } & Sand $(0.05-2 \mathrm{~mm})$ & $\%$ & 68 & 76 & 73 & 75 \\
\hline & Silt $(0.002-0.05 \mathrm{~mm})$ & $\%$ & 29 & 22 & 22 & 23 \\
\hline & Clay $(<0.002 \mathrm{~mm})$ & $\%$ & 3 & 2 & 5 & 2 \\
\hline \multicolumn{3}{|c|}{ Textural group (USDA) } & SL & LS & SL & LS \\
\hline \multicolumn{2}{|c|}{ C org. } & $\mathrm{g} / \mathrm{kg}$ & 14.1 & 16.3 & 18.0 & 29.5 \\
\hline \multicolumn{2}{|l|}{$\mathrm{N}$ total } & $\mathrm{g} / \mathrm{kg}$ & 1.05 & 1.23 & 1.22 & 1.81 \\
\hline \multicolumn{2}{|l|}{$\mathrm{CaCO}_{3}$} & $\%$ & 0.1 & 1.3 & - & - \\
\hline \multicolumn{2}{|l|}{$\mathrm{pH}\left(\mathrm{H}_{2} \mathrm{O}\right)$} & - & 7.1 & 7.6 & 4.8 & 6.5 \\
\hline \multicolumn{2}{|l|}{ Feox } & $\mathrm{g} / \mathrm{kg}$ & 28.55 & 23.95 & 23.70 & 3.50 \\
\hline \multicolumn{2}{|c|}{ Total As (aqua regia) } & $\mathrm{mg} / \mathrm{kg}$ & 45,500 & 50,000 & 12,150 & 196 \\
\hline \multirow{2}{*}{\multicolumn{2}{|c|}{ As extracted with $1 \mathrm{M} \mathrm{NH}_{4} \mathrm{NO}_{3}$}} & $\mathrm{mg} / \mathrm{kg}$ & 8.04 & 7.89 & 0.07 & 0.06 \\
\hline & & $\%$ of total & 0.018 & 0.016 & 0.001 & 0.031 \\
\hline \multirow{2}{*}{\multicolumn{2}{|c|}{ As extracted with $0.01 \mathrm{M} \mathrm{CaCl}_{2}$}} & $\mathrm{mg} / \mathrm{kg}$ & 24.3 & 11.3 & 0.27 & $<0.12$ \\
\hline & & $\%$ of total & 0.053 & 0.023 & 0.002 & n.d. \\
\hline
\end{tabular}

Presented data are the mean values of three replicates

n.d. not determined 
The degree of BL humification and fractional composition of its humic substances were determined according to a modified Tiurin's method, developed and commonly used in Polish soil science (Łabaz and Gałka 2012). The operationally defined procedure is based on a multiple sequential extraction of acid- and base-soluble fractions, including the steps of extraction with acid (fraction 1a), exhaustive extraction with $0.1 \mathrm{M} \mathrm{NaOH}$ (fraction 1), as well as the alternate treatment with $\mathrm{NaOH}$ and $\mathrm{H}_{2} \mathrm{SO}_{4}$ supposed to destroy the bonds of organic molecules with mineral compounds (fraction 3). Four fractions of humic substances were distinguished: 1a, 1, 2, and 3 (Table 2). The fraction 1a contained "aggressive fulvic acids". The fractions 1 and 2 contained the mixtures of fulvic and humic acids, and in each of those fractions, the share of fulvic subfraction was determined based on the treatment of its aliquot with $5 \mathrm{M} \mathrm{H}_{2} \mathrm{SO}_{4}$. The values of humic to fulvic acid ratio (CHA:CFA) were determined based on the fractions 1a, 1 , and 2, while a humification index was calculated based on the share of non-hydrolyzing carbon in BL.

\subsection{Incubation experiment}

Soils were incubated for 90 days in $1-\mathrm{kg}$ pots at various moistures: $80 \%$ of water holding capacity and $100 \%$ (waterlogged - at maximum water capacity) with and without addition of beech forest litter BL. The BL was mixed with soil at the rate $50 \mathrm{~g} / \mathrm{kg}$ on dry matter basis. After $2,7,14,28$, and 90 days of incubation, soil pore water was collected with MacroRhizon suction samplers, made of porous plastic material PES (Eijkelkamp), and examined on chemical composition and optical properties. The experiment was carried out in three replicates, and the data presented in the graphs illustrate the mean values and confidence intervals at $p=0.95$.

\subsection{Pore water analysis}

Pore water samples were filtered through a $0.45-\mu \mathrm{m}$ membrane and analyzed promptly after collecting. The concentrations of total As were determined by ICP-AES AES (Thermo Scientific, iCAP 7400). Additionally, the concentrations of $\mathrm{Mn}$ and $\mathrm{Fe}$ that get released into solution under reducing conditions were included in the analysis by ICP$\mathrm{AES}$ at the end of incubation. The values of $\mathrm{pH}$ and Eh were determined potentiometrically, and dissolved organic carbon (DOC) concentrations were measured spectrophotometrically, using a standard method with Merck 1.14878.0001 test. The properties of DOC were characterized by A4/A6 and $\mathrm{SUVA}_{254}$ indices based on the light absorbance at 254, 465, and $665 \mathrm{~nm}$ (Leenheer and Croué 2003), determined by an UV-VIS spectrophotometer Agilent Cary 60. Possible effects of nitrate and iron ions present in solutions on the values of $\mathrm{SUVA}_{254}$ (Weishaar et al. 2003) were checked in selected samples by standard addition and assessed as negligible.
Table 2 Basic properties and fractional composition of beech forest litter

\begin{tabular}{|c|c|c|}
\hline Parameter & Unit & $\begin{array}{l}\text { Mean } \\
\text { value }\end{array}$ \\
\hline Total organic carbon & $\mathrm{g} / \mathrm{kg}$ & 418 \\
\hline $\mathrm{N}$ total & $\mathrm{g} / \mathrm{kg}$ & 17.4 \\
\hline DOC & $\mathrm{g} / \mathrm{kg}$ & 3.95 \\
\hline $\mathrm{SUVA}_{254}$ of water extract & $\mathrm{L} / \mathrm{mg} \cdot \mathrm{m}$ & 0.28 \\
\hline A4:A6 of water extract & - & 12.7 \\
\hline $\mathrm{pH}\left(\mathrm{H}_{2} \mathrm{O}\right)$ & - & 5.95 \\
\hline $\begin{array}{l}\text { Fraction 1a (fulvic) }-0.05 \mathrm{M} \mathrm{H}_{2} \mathrm{SO}_{4^{-}} \\
\quad \text { soluble } \mathrm{C} \text { (extraction repeated } 4 \text { times) }\end{array}$ & $\%$ of total & 14.9 \\
\hline $\begin{array}{l}\text { Fraction 1: } 0.1 \mathrm{M} \mathrm{NaOH} \text {-extractable } \mathrm{C} \\
\text { (multiple, exhaustive extraction). Here, } \\
\text { it was repeated } 6 \text { times. }\end{array}$ & $\%$ of total & 37.9 \\
\hline $\begin{array}{l}\text { Fraction } 2 \text { : } \mathrm{C} \text { strongly bound to mineral } \\
\text { compounds (obtained by the alternate } \\
\text { extraction with } 0.1 \mathrm{M} \mathrm{H}_{2} \mathrm{SO}_{4} \text { and } 0.1 \\
\mathrm{M} \mathrm{NaOH} \text { ), repeated } 3 \text { times }\end{array}$ & $\%$ of total & 25.5 \\
\hline $\begin{array}{l}\text { Fraction 3: non-extractable C } \\
\quad \text { (residual fraction) }\end{array}$ & $\%$ of total & 21.6 \\
\hline CHA:CFA in fraction 1 & - & 0.98 \\
\hline CHA:CFA in fraction 2 & - & 1.20 \\
\hline Humification index & $\%$ & 78 \\
\hline
\end{tabular}

Fractionation according to modified method by Tiurin (Labaz and Gałka 2012)

\subsection{Statistics}

The differences among the treatments and times have been analyzed by two-way ANOVA, followed by post hoc multiple comparison of means carried out by a Tukey's test $(P<0.05)$. Statistical analysis was performed using a software Statistica, version 10.0 (Statsoft).

\section{Results}

\subsection{Soil properties}

All mine dump samples were strongly skeletic (50-80\%). Their earthy fraction that was used in the experiment differed considerably in chemical features (Table 1), correspondingly to the sites of their collection and geological settings. The properties of soils ZS1 and ZS2 were similar; they had neutral (ZS1) or slightly alkaline (ZS2) pH and contained high concentrations of As: 4.55 and $5.00 \%$, respectively. Soil R contained $1.21 \%$ As and had acidic reaction ( $\mathrm{pH} 4.8$ ). Soil DM was much poorer in As $(196 \mathrm{mg} / \mathrm{kg})$ and indicated a slightly acidic reaction, $\mathrm{pH}$ 6.5. All soils, in spite of their initial stage of development, contained considerable amounts of organic $\mathrm{C}$, which was in the $14.1-29.5-\mathrm{g} / \mathrm{kg}$ range. Arsenic extractability, determined with $0.01 \mathrm{M} \mathrm{CaCl}_{2}$ and $1 \mathrm{M} \mathrm{NH}_{4} \mathrm{NO}_{3}$, was by two orders larger in ZS soils than in the others; 
however, the amounts of extractable As did not differ considerably between the soils R and DM despite the large differences in their total As concentrations. It is worth noticing the As extracted with neutral salts from soil $\mathrm{R}$ represented a fraction of the total As content that was orders of magnitude smaller in comparison with the other soils. Such effect may be associated with acidic character of this soil and its parent rock, but this hypothesis should be checked in a further study.

\subsection{The properties of forest litter}

Forest litter BL contained $418 \mathrm{~g} / \mathrm{kg}$ of total organic carbon, in which the share of cold water-soluble organic compounds (DOC) was relatively high, i.e., $3.95 \mathrm{~g} / \mathrm{kg}$ (Table 2). The data provided by an operationally defined sequential extraction of organic matter indicated a pretty large share of acid-soluble, "aggressive" fulvic, fraction 1a (14.9\% of total organic carbon.), and at the same time a moderate ratio of humic to fulvic acids (CHA:CFA). The calculated value of a humification index, based on that rate, was considerably high (78\%), despite the fact that the BL layer in fact did not contain a real humus, i.e., a well-humified material. It should be stressed that the fraction denoted as the fulvic acids are of a particular importance from the standpoint of possible leaching, as it can be dissolved independently on soil $\mathrm{pH}$, whereas the other fractions can be solubilized only in alkaline conditions or are almost insoluble.

\subsection{Initial release of As into solution}

The first series of pore water analysis (after 2 days of incubation) showed that particularly large amounts of As were released from the soils ZS1 and ZS2. The concentrations of As in soil pore water of those soils, in various treatments, were at that time in the range $7.4-24.5 \mathrm{mg} / \mathrm{L}$, i.e., by two orders higher than those in pore water of $\mathrm{R}$ and DM soils, which remained then (after a 2-day incubation) in the range $0.025-0.374 \mathrm{mg} / \mathrm{L}$ (Fig. 2).

Addition of forest litter to all soils increased the mobilization of As from the soil solid phase into solution; however, after the first 2 days of incubation, this effect was relatively poorly expressed, particularly in ZS soils, though it became much more pronounced, and statistically significant (Table S1 in the Electronic Supplementary Material), after a longer time of the experiment (Fig. 2).

\subsection{Effects of incubation time}

The concentrations of As in soil solution tended to significantly increase during the first 2 weeks - both in BL-treated and in untreated soils (Fig. 2). In the soil solutions acquired from the soils treated with BL, As concentrations were by 10 -fold or even more higher than those in the solutions collected from untreated soils. A strong increase in As concentrations in soil pore water, observed during the first 2 weeks of incubation, was associated with a strong increase in DOC concentrations (Fig. 2). Then, the concentrations of DOC in soil pore water started to decrease in most of experimental treatments, while the concentrations of As in most cases continued to increase until the 28 days and in some samples - under anoxic conditions - until the end of incubation (90 days) (Fig. 2). The maximum As concentration in pore water, $384 \mathrm{mg} / \mathrm{L}$, was reported from waterlogged ZS2 soil, at the end of incubation.

The concentrations of $\mathrm{Fe}$ in the pore water of all soils treated with BL and incubated at $80 \%$ of water capacity were at the end of incubation extremely low, i.e., below a determination level of ICP-AES $(0.1 \mathrm{mg} / \mathrm{L})$. Mn concentrations remained also low in the pore water of ZS soils; however, a considerable release of $\mathrm{Mn}$ from the $\mathrm{R}$ soil, and also from DM, was confirmed by increased $\mathrm{Mn}$ concentrations in soil pore water (Table 3). A relatively high Eh value $(236 \mathrm{mV})$ indicates that this effect was associated with acidic soil $\mathrm{pH}$ rather than with reductive dissolution of $\mathrm{Mn}$. In fact, reductive dissolution of $\mathrm{Mn}$ in waterlogged soils is governed by the couple of $\mathrm{pH}$-Eh values. Therefore, the concentrations of $\mathrm{Mn}$ and $\mathrm{Fe}$ in the pore water of waterlogged ZS soil samples were at the end of incubation very low, despite the low values of Eh that are usually indicative of development of reducing conditions. On the contrary, Fe and Mn concentrations in waterlogged R and DM soils treated with BL were slightly higher or even very high. In the case of R soil, they reached the values of 220 and $310 \mathrm{mg} /$ $\mathrm{L}$, respectively.

Spectroscopic analysis of soil pore water from BL-treated soils indicated that generally the values of $\mathrm{SUVA}_{254}$ started to considerably increase after 14 or 28 days of incubation, and at the same time, the values of A4:A6 started to decrease (Fig. 3). Such a tendency was observed for all BL-treated soils. This simple effect may be considered as a result of a step-wise transformation of dissolved organic matter. The dissolved $\mathrm{OM}$ at the end of incubation showed an increased humic character, which should probably be ascribed to a progressive residual accumulation of more recalcitrant, aromatic compounds derived both from BL and from soil native organic matter.

\section{Discussion}

The concentrations of As in the pore water from various soils were undoubtedly determined by soil properties and the As speciation in soil. The differences between soils ZS1 and ZS2 on one side and $\mathrm{R}$ and $\mathrm{DM}$ on the other were apparently related to soil properties, in particular to total concentrations of As in soils (extremely high in ZS soils), and also to its potential solubility in soil solid phase, reflected by extractability in $1 \mathrm{M} \mathrm{NH}_{4} \mathrm{NO}_{3}$ and $0.01 \mathrm{M} \mathrm{CaCl}_{2}$ (Table 1). 

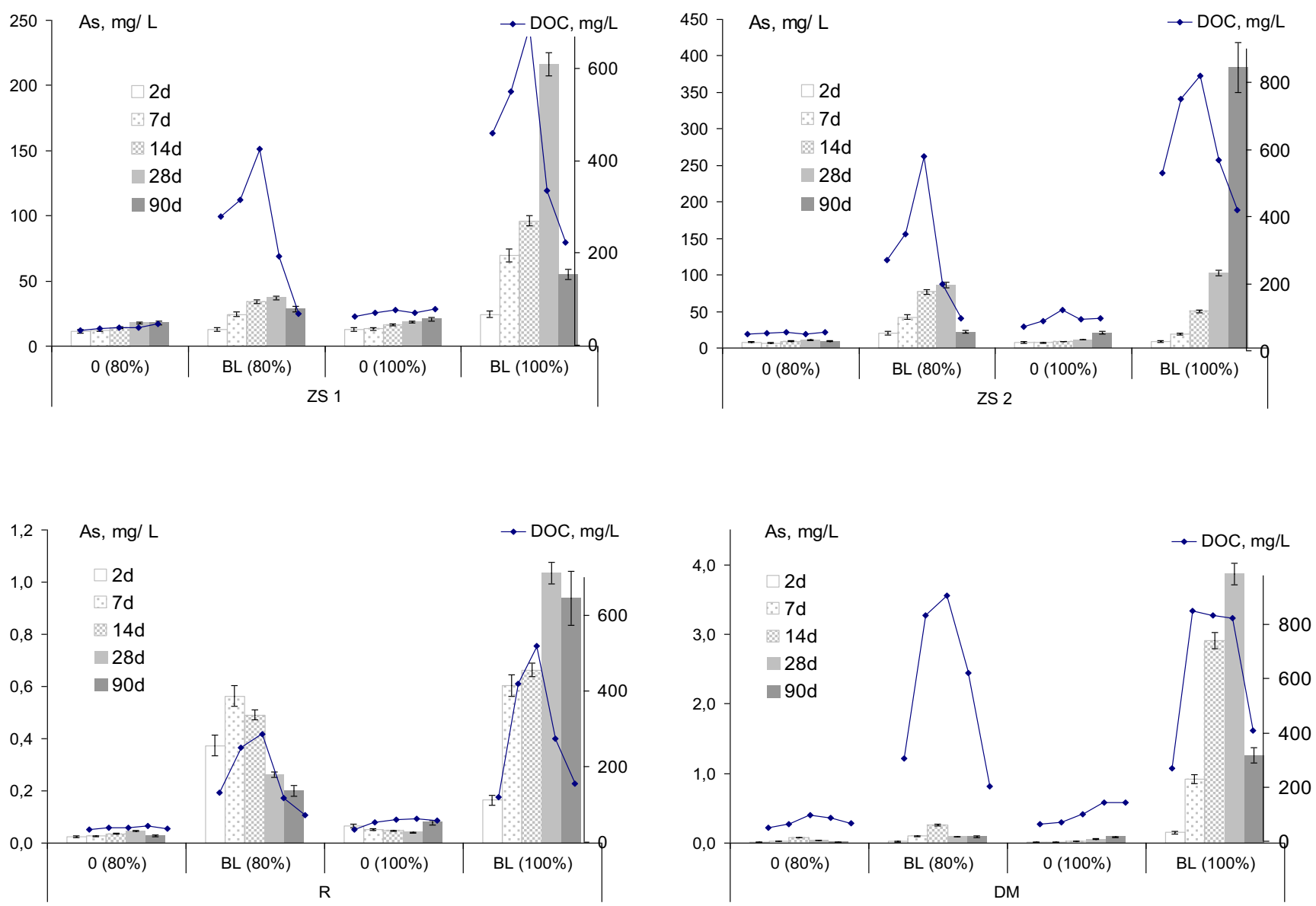

Fig. 2 Concentrations of As and DOC in soil pore water collected from soils ZS1, ZS2, R, and DM, treated with beech forest litter (BL) and non-treated (0), incubated for $2,7,14,28$, and 90 days at the moisture of 80 and $100 \%$ of water capacity

The enhanced release of As from soils, caused their by treatment with BL, was unambiguously confirmed for all the soils included in the experiment, both under the conditions of $80 \%$ moisture and in waterlogged soils. In the latter case, the amounts of As released into solutions from all soils were particularly high. This observation stays in agreement with a common knowledge on As biogeochemistry in the soil environment (Kabata-Pendias 2011; Wenzel 2013; Komárek et al. 2013) and with the results widely reported in the literature. DOM-induced mobilization of As from soils involves various mechanisms. Under oxidized conditions, it is usually attributed to the competition for sorption sites on Fe oxides, whereas in anoxic environment, several other processes are involved, including reductive dissolution of oxides (Bauer and Blodau 2006; Wang and Mulligan 2006; Moreno-Jiménez et al. 2013; Xie et al. 2015).

Two aspects of our study seem to be particularly interesting: (i) the comparison of As release from neutral (or alkaline) ZS soils and from more acidic, carbonate-free soils and (ii) the long-term changes in As solubility under oxidized and anoxic conditions.
Table $3 \mathrm{Mn}$ and $\mathrm{Fe}$ concentrations, as well as $\mathrm{pH}$ and Eh values, measured in pore water of BL-treated soils after 90 days of incubation

\begin{tabular}{|c|c|c|c|c|c|c|c|c|}
\hline \multirow[t]{2}{*}{ Soil } & \multicolumn{4}{|c|}{ Oxidized conditions, $80 \%$ moisture } & \multicolumn{4}{|c|}{ Anoxic conditions, $100 \%$ moisture (waterlogged soils) } \\
\hline & $\mathrm{Fe}, \mathrm{mg} / \mathrm{L}$ & $\mathrm{Mn}, \mathrm{mg} / \mathrm{L}$ & $\mathrm{pH}$ & $\mathrm{Eh}, \mathrm{mV}$ & $\mathrm{Fe}, \mathrm{mg} / \mathrm{L}$ & $\mathrm{Mn}, \mathrm{mg} / \mathrm{L}$ & $\mathrm{pH}$ & $\mathrm{Eh}, \mathrm{mV}$ \\
\hline ZS1 & $<0.100^{\mathrm{a}}$ & $<0.024^{\mathrm{a}}$ & $7.42^{\mathrm{a}}$ & $180^{\mathrm{b}}$ & $1.194^{\mathrm{b}}$ & $1.26^{\mathrm{b}}$ & $7.62^{\mathrm{a}}$ & $65^{\mathrm{a}}$ \\
\hline ZS2 & $<0.100^{\mathrm{a}}$ & $0.459^{\mathrm{b}}$ & $8.32^{\mathrm{a}}$ & $135^{\mathrm{b}}$ & $0.819^{\mathrm{b}}$ & $0.069^{\mathrm{a}}$ & $8.30^{\mathrm{a}}$ & $38^{\mathrm{a}}$ \\
\hline $\mathrm{R}$ & $<0.100^{\mathrm{a}}$ & $12.5^{\mathrm{a}}$ & $5.80^{\mathrm{a}}$ & $236^{\mathrm{b}}$ & $220^{\mathrm{b}}$ & $310^{\mathrm{b}}$ & $6.11^{\mathrm{b}}$ & $130^{\mathrm{a}}$ \\
\hline $\mathrm{DM}$ & $<0.100^{\mathrm{a}}$ & $0.122^{\mathrm{a}}$ & $6.95^{\mathrm{b}}$ & $210^{\mathrm{b}}$ & $3.4^{\mathrm{b}}$ & $9.5^{\mathrm{b}}$ & $6.70^{\mathrm{a}}$ & $110^{\mathrm{a}}$ \\
\hline
\end{tabular}

Same letters indicate the mean values of parameters that do not differ significantly (at $P<0.95$ ) between oxidized and anoxic conditions 
Fig. 3 The changes of spectral parameters A4:A6 and $\mathrm{SUVA}_{254}$ of pore water collected from BLtreated soils

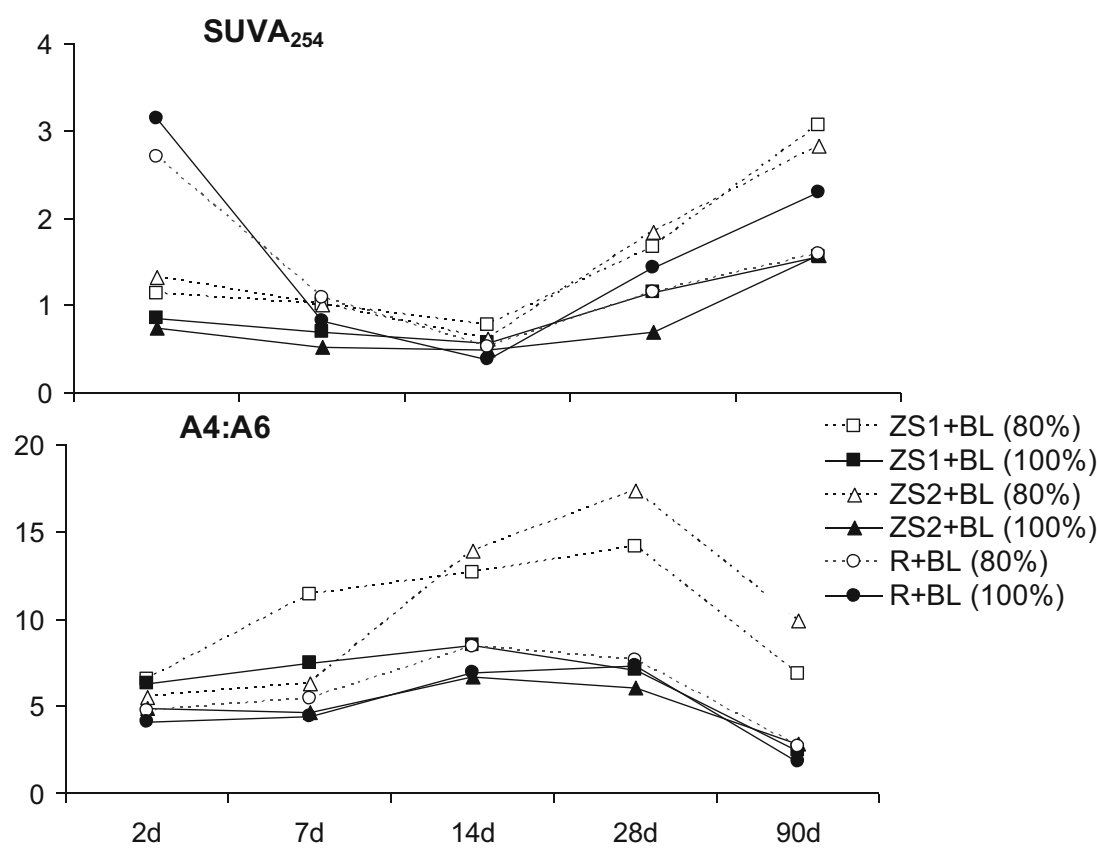

waterlogged, ZS soils remained high for a long time. Apart from the reductive dissolution of adsorbing soil phases, i.e., oxides (Bauer and Blodau 2006; Blodau et al. 2008; Wenzel 2013; Shaheen et al. 2014), that takes place under anoxic conditions, also As (V) gets reduced to As (III), a species that has much lower affinity to soil sorption sites. Moreover, the sorption of As (III) is believed to decrease with increasing $\mathrm{pH}$ in the $\mathrm{pH}$ range 8-10 (Casiot et al. 2007).

An initial release of As from all BL-treated soils under oxidized conditions ( $80 \%$ moisture), though much smaller than that in waterlogged soils, should be explained mainly by a competition for sorption sites on Fe oxides.

A decrease in As concentrations in soil pore water, in the latest phases of incubation, except for the waterlogged ZS2, is a well-known phenomenon, based on various mechanism, referred to as "aging "of contaminants (Pigna et al. 2006). Similar patterns were described for $\mathrm{Cu}$ in forest litter treated, contaminated soils (Cuske et al. 2017). This effect may be first of all explained by reduction in DOC concentrations, due to partial mineralization of dissolved organic matter and a selective preservation of the more aromatic, litter-derived molecules, which was associated with increasing condensation degree and aromaticity of particles. Such changes were confirmed in case of two ZS soils by a decrease of A4:A6 index as well as by increase of $\mathrm{SUVA}_{254}$ after 14 or 28 days of incubation. Similar changes in SUVA were described by Said-Pullicino et al. (2016) in submerged soils. The litterderived compounds as well as, most probably, some soilderived substances released in the long term into the pore water have probably a potential to bind arsenates and to be, as such complexes, sorbed onto soil solid phase, contributing in that way to As removal from soil solution. A decrease in As 
concentrations in soil pore water after longer duration may also be attributed to microbial growth, accompanied by an incorporation of the contaminant into microbial biomass.

\section{Conclusions}

1. Beech forest litter BL affects strongly the solubility of As in mine dump soils and may therefore cause a strong increase in As concentrations in soil pore water, first of all in waterlogged soils, but also in oxidized conditions. This effect may cause a release of As into natural water, thus being a factor of increasing environmental risk.

2. An increase in As concentrations in soil pore water, induced by forest litter, is a temporary phenomenon that lasts several weeks and is usually followed by considerable decrease along with decreasing DOC concentrations.

3. The extent of As release from soil solid phase depends on its total concentrations in soils and on the composition, mineralogy, and other properties, in particular $\mathrm{pH}$, of soil parent material. Soil carbonates seem therefore to be of particular importance, as alkaline $\mathrm{pH}$ favors As desorption and dissolution of organic matter. Additionally, hypothetical formation of As complexes with carbonates may contribute to As mobilization under reducing conditions. The release of As from acidic BL-treated soils likely involved the competition for sorption sites on $\mathrm{Fe}$ oxides in oxidized soils and reductive dissolution of oxides under anoxic conditions.

4. Increasing condensation and aromaticity of dissolved organic matter seem to be the considerable factors that contribute to the process of As aging in some of BL-treated soils and support its sorption on soil solid phase. This mechanism has not been fully recognized; therefore, the study on As aging should be continued with considering more comprehensive analytical methods, including speciation of DOM as well as speciation of As both in soil solid phase and in the pore water.

Acknowledgements This research was supported by the National Science Centre of Poland, Project Nos. 2014/13/B/ST10/02978 and 2016/21/B/ST10/02221.

Open Access This article is distributed under the terms of the Creative Commons Attribution 4.0 International License (http:// creativecommons.org/licenses/by/4.0/), which permits unrestricted use, distribution, and reproduction in any medium, provided you give appropriate credit to the original author(s) and the source, provide a link to the Creative Commons license, and indicate if changes were made.

\section{References}

Arco-Lázaro E, Agudo I, Clemente R, Bernal MP (2016) Arsenic (V) adsorption-desorption in agricultural and mine soils: effects of organic matter addition and phosphate competition. Environ Pollut 216:71-79
Bauer M, Blodau C (2006) Mobilization of arsenic by dissolved organic matter from iron oxides, soils and sediments. Sci Total Environ 354: $179-190$

Berg B (2017) Decomposing litter, limit values, humus accumulation, locally and regionally. Appl Soil Ecol. https://doi.org/10.1016/j. apsoil.2017.06.026

Blaser P, Zimmermann S, Luster J, Shotyk W (2000) Critical examination of trace element enrichments and depletions in soils: $\mathrm{As}, \mathrm{Cr}, \mathrm{Cu}, \mathrm{Ni}$, $\mathrm{Pb}$, and $\mathrm{Zn}$ in Swiss forest soils. Sci Total Environ 249(1):257-280

Blodau C, Fulda B, Bauer M, Knorr KH (2008) Arsenic speciation and turnover in intact organic soil mesocosms during experimental drought and rewetting. Geoch Cosmochim Acta 72(16):3991-4007

Bolan N, Mahimairaja S, Kunhikrishnan A, Choppala G (2013) Phosphorus-arsenic interactions in variable-charge soils in relation to arsenic mobility and bioavailability. Sci Total Environ 463:11541162

Brun CB, Åström ME, Peltola P, Johansson MB (2008) Trends in major and trace elements in decomposing needle litters during a long-term experiment in Swedish forests. Plant Soil 306(1-2):199-210

Carbonell-Barrachina A, Jugsujinda A, Delaune RD, Patrick WH, Burlo F, Sirisukhodom S, Anurakpongsatorn P (1999) The influence of redox chemistry and $\mathrm{pH}$ on chemically active forms of arsenic in sewage sludge amended soil. Environ Int 25(5):613-618

Casiot C, Ujevic M, Munoz M, Seidel JL, Elbaz-Poulichet F (2007) Antimony and arsenic mobility in a creek draining an antimony mine abandoned 85 years ago (upper Orb basin, France). Appl Geochem 22(4):788-798

Chen Y, Senesi N, Schnitzer M (1977) Information provided on humic substances by E4/E6 ratios. Soil Sci Soc Am J 41(2):352-358

Cuske M, Karczewska A, Gałka B, Matyja K (2017) Would forest litter cause a risk of increased copper solubility and toxicity in polluted soils remediated via phytostabilization? Pol J Environ St 26(1):419423

Fakhreddine S, Dittmar J, Phipps D, Dadakis J, Fendorf S (2015) Geochemical triggers of arsenic mobilization during managed aquifer recharge. Environ Sci Technol 49(13):7802-7809

González AZI, Krachler M, Cheburkin AK, Shotyk W (2006) Spatial distribution of natural enrichments of arsenic, selenium, and uranium in a minerotrophic peatland, Gola di Lago, Canton Ticino, Switzerland. Environ Sci Technol 40:6568-6574

Gregorich EG, Beare MH, Stoklas U, St-Georges P (2003) Biodegradability of soluble organic matter in maize-cropped soils. Geoderma 113(3):237-252

Han MJ, Hao J, Christodoulatos C, Korfiatis GP, Wan LJ, Meng X (2007) Direct evidence of arsenic (III)-carbonate complexes obtained using electrochemical scanning tunneling microscopy. Anal Chem 79(10): 3615-3622

Hindmarsh JT, McLetchle OR, Heffernan LP, Hayne OA, Ellenberger HA, McCurdy RF, Thiebaux HJ (1977) Electromyographic abnormalities in chronic environmental arsenicalism. J Anal Toxicol 1(6): 270-276

Houba VJG, Temminghoff EJM, Gaikhorst GA, Van Vark W (2000) Soil analysis procedures using $0.01 \mathrm{M}$ calcium chloride as extraction reagent. Commun Soil Sci Plant Anal 31(9-10):1299-1396

ISO 19730:2008 (2008) Soil quality - extraction of trace elements from soil using ammonium nitrate solution

Kabała C, Karczewska A, Medyńska-Juraszek A (2014) Variability and relationships between $\mathrm{Pb}, \mathrm{Cu}$, and $\mathrm{Zn}$ concentrations in soil solutions and forest floor leachates at heavily polluted sites. J Plant Nutr Soil Sci 177:573-584

Kabata-Pendias A (2011) Trace elements in soils and plants, 4th edn. CRC Press, Boca Raton

Kalbitz K, Wennrich R (1998) Mobilization of heavy metals and arsenic in polluted wetland soils and its dependence on dissolved organic matter. Sci Total Environ 209(1):27-39 
Karczewska A, Bogda A, Krysiak A (2007) Arsenic in soils in the areas of former arsenic mining and processing in Lower Silesia, SW Poland. In: Bhattacharya P, Mukherjee AB Loeppert RH (eds) Arsenic in soil and groundwater environments: biogeochemical interactions. Elsevier book series: trace metals and other contaminants in the environment; Series Editor: Jerome O. Nriagu. Volume 9, Chapter 16, p 411-440

Karczewska A, Gałka B, Gersztyn L, Popielas K (2013a) Effects of forest litter on copper and zinc solubility in polluted soils, examined in a pot experiment. Fres Environ Bull 22:949-954

Karczewska A, Krysiak A, Mokrzycka D, Jezierski P, Szopka K (2013b) Arsenic distribution in soils of a former As mining area and processing. Pol J Environ Stud 22:175-181

Karczewska A, Gałka B, Dradrach A, Lewińska K, Mołczan M, Cuske M, Gersztyn L, Litak K (2017) Solubility of arsenic and its uptake by ryegrass from polluted soils amended with organic matter. J Geochem Explor 182(Part B):193-200

Kathe J (1937) Das Arsen-Vorkommen bei Reichenstein und die sogenannte Reichensteiner Krankheit. 110 Jahresber Schles Ges Vaterl Kultur Med Wiss Reihe, No. 4. Ferdinand Hirt, Breslau

Kawałko D, Halarewicz A, Kaszubkiewicz J, Jezierski P (2017) Decomposition rate of the litter fall in the course of riparian habitat changes. Sylwan 161(7):565-572

Kim MJ, Nriagu J, Haack S (2000) Carbonate ions and arsenic dissolution by groundwater. Environ Sci Technol 34(15):3094-3100

Komárek M, Vaněk A, Ettler V (2013) Chemical stabilization of metals and arsenic in contaminated soils using oxides - a review. Environ Pollut 172:9-22

Krysiak A, Karczewska A (2007) Arsenic extractability in soils in the areas of former arsenic mining and smelting, SW Poland. Sci Total Environ 379:190-200

Krysiak A, Karczewska A (2011) Effects of soil flooding on arsenic mobility in soils in the area of former gold and arsenic mining in Zloty Stok. Soil Sci Ann LXII(2):240-248

Łabaz B, Gałka B (2012) Characteristics of soil organic matter in ectohumus horizons of forest soils in the Stołowe mountains. Pol J Soil Sci 45(1):49-56

Łabaz B, Szopka K, Jezierski P, Waroszewski J, Kabała C (2016) Fractional composition of humus in selected forest soils in the Karkonosze Mountains. Pol J Soil Sci 45(1):83

Langner P, Mikutta C, Kretzschmar R (2012) Arsenic sequestration by organic sulphur in peat. Nat Geosci 5(1):66-73

Leenheer JA, Croué JP (2003) Peer reviewed: characterizing aquatic dissolved organic matter. Environ Sci Technol 37(1):18A-26A

Lewińska K, Karczewska A (2013) Influence of soil properties and phosphate addition on arsenic uptake from polluted soils by velvet grass (Holcus lanatus). Int J Phytoremed 15(1):91-104

Marschner B, Kalbitz K (2003) Controls of bioavailability and biodegradability of dissolved organic matter in soils. Geoderma 113(3):211235

Martin M, Bonifacio E, Hossain KJ, Huq SI, Barberis E (2014) Arsenic fixation and mobilization in the soils of the Ganges and Meghna floodplains. Impact of pedoenvironmental properties. Geoderma 228:132-114

Mikulski SZ (1999) Gold from Radzimowice deposit in Kaczawa Mts. (Sudetes) - new geochemical and mineralogical data (SW Poland). Prz Geol 47:999-1005

Moreno-Jiménez E, Clemente R, Mestrot A, Meharg AA (2013) Arsenic and selenium mobilisation from organic matter treated mine spoil with and without inorganic fertilisation. Environ Pollut 173:238244
Muszer A, Szuszkiewicz A, Łobos K (2006) New occurrence of Clausthalite $(\mathrm{PbSe})$ in the Sudetes (SW Poland). Fortschr Mineral 37(2):123-132

Pigna M, Krishnamurti GSR, Violante A (2006) Kinetics of arsenate sorption-desorption from metal oxides. Soil Sci Soc Am J 70(6): 2017-2027

Saada A, Breeze D, Crouzet C, Cornu S, Baranger P (2003) Adsorption of arsenic $(\mathrm{V})$ on kaolinite and on kaolinite-humic acid complexes: role of humic acid nitrogen groups. Chemosphere 51(8):757-763

Said-Pullicino D, Miniotti EF, Sodano M, Bertora C, Lerda C, Chiaradia EA, Celi L (2016) Linking dissolved organic carbon cycling to organic carbon fluxes in rice paddies under different water management practices. Plant Soil 401(1-2):273-290

Shaheen SM, Rinklebe J, Rupp H, Meissner R (2014) Lysimeter trials to assess the impact of different flood-dry-cycles on the dynamics of pore water concentrations of $\mathrm{As}, \mathrm{Cr}, \mathrm{Mo}$ and $\mathrm{V}$ in a contaminated floodplain soil. Geoderma 228:5-13

Silvetti M, Garau G, Demurtas D, Marceddu S, Deiana S, Castaldi P (2017) Influence of lead in the sorption of arsenate by municipal solid waste composts: metal(loid) retention, desorption and phytotoxicity. Bioresour Technol 225:90-98

Strobel BW, Hansen HCB, Borggaard OK, Andersen MK, RaulundRasmussen K (2001) Composition and reactivity of DOC in forest floor soil solutions in relation to tree species and soil type. Biogeochemistry 56(1):1-26

Swift RS (1996) Organic matter characterization. In: Methods of soil analysis. Part 3. Chemical methods-SSSA Book Series no. 5, Madison, pp 1011-1068

Tan KH (2005) Soil sampling, preparation, and analysis. 2nd ed. CRC Press

Thanabalasingam P, Pickering WF (1986) Arsenic sorption by humic acids. Environ Pollut 12:233-246

Van Nevel L, Mertens J, De Schrijver A, Baeten L, De Neve S, Tack FM, Verheyen K (2013) Forest floor leachate fluxes under six different tree species on a metal contaminated site. Sci Total Environ 447:99107

Van Nevel L, Mertens J, Demey A, De Schrijver A, De Neve S, Tack FM, Verheyen K (2014) Metal and nutrient dynamics in decomposing tree litter on a metal contaminated site. Environ Pollut 189:54-62

Wang S, Mulligan CN (2006) Effect of natural organic matter on arsenic release from soil and sediments into groundwater. Environ Geochem Health 28:197-214

Weber FA, Hofacker AF, Voegelin A, Kretzschmar R (2009) Temperature dependence and coupling of iron and arsenic reduction and release during flooding of a contaminated soil. Environ Sci Technol 44(1): $116-122$

Weishaar JL, Aiken GR, Bergamaschi BA, Fram MS, Fujii R, Mopper K (2003) Evaluation of specific ultraviolet absorbance as an indicator of the chemical composition and reactivity of dissolved organic carbon. Environ Sci Technol 37(20):4702-4708

Wenzel WW (2013) Arsenic. In: Alloway BJ (ed) Heavy metals in soils. Trace metals and metalloids in soils and their bioavailability. 3rd edn, Springer, pp 241-282

Wierchowiec J, Wojciechowski A (2010) Auriferous wastes from the abandoned arsenic and gold mine in Złoty Stok (Sudetes Mts., SW Poland). Geol Q 53(2):233-240

Xie H, Han D, Cheng J, Zhou P, Wang W (2015) Fate and risk assessment of arsenic compounds in soil amended with poultry litter under aerobic and anaerobic circumstances. Water Air Soil Pollut 226(11):1-11 